\title{
af Reducing Draft Force Required For Breaking Soil Surface Crust By Using Organic Materials
}

\section{M.Sc. Thesis, Agricultural Soil and Chemistry Department, Faculty of Agriculture - Saba Basha, Alexandria University}

\author{
M. A. Ebrahim ${ }^{1}$, A.M. Zein El-Din ${ }^{2}$, M.A.E. Hossain ${ }^{3}$, G.A. Sharaf ${ }^{4}$ \\ Editors: Gomaa, M. A. E;
}

${ }^{1}$ Intellectual Property Expert at SMAS Intellectual Property Company, Egypt.

${ }^{2}$ Professor of Agricultural Engineering and biological systems \& Dean of Faculty of Agriculture - ElShatby- Alexandria University https://orcid.org/0000-0002-7468-9299/print

${ }^{3}$ Professor Soil Science, \& Vic Dean of Faculty of Agriculture - Saba Basha - Alexandria University

${ }^{4}$ Professor Agricultural Engineering, Agricultural Soil and Chemistry Department - Faculty of Agriculture - Saba Basha - Alexandria University.

\section{DOI: 10.21608/jalexu.2021.187409}

Article Information

Received:June $29^{\text {th }} 2021$

Revised: August $1^{\text {st }} 2021$

Accepted: August $1^{\text {st }} 2021$

Published: December $31^{\text {st }}$ 2021

ABSTRACT Soil surface crust is a major problem facing the agricultural development. This study aims to investigate the effect of some treatments on the draft force required to break the soil crust.

A series of experiments were carried out to investigate the effect of different compaction levels, organic material types and organic materials application rates on the draft force required to break the soil crust under surface irrigation conditions.

The tested soil was sandy loam soil with $16.45 \% \mathrm{CaCO} 3$ content collected from the Egyptian North Coast at El-Hammam city, Marsa Matrouh governorate. A split plot experimental design was incorporated, with two types of crust (wet and dry), three compaction levels (non compaction, medium level $22 \mathrm{KPa}$, and heavy level $44 \mathrm{KPa}$ ), two types of organic materials (cattle manure and compost manure), and three application rates of organic materials $(10,20$, and $30 \mathrm{~m} 3 / \mathrm{fed})$.

The draft force studied in a fully automated computer programmed soil bin facility using a small coulter.

The results indicates that compaction level had a vice effect of the soil crust characteristics. Increasing compaction level increased the draft force required to break the soil surface crust by about 22 and $33 \%$ for medium and heavy compaction levels respectively. Manure matter improves soil surface crust characteristics. Medium level of cattle manure $(20 \mathrm{~m} 3 / \mathrm{fed})$ with no compaction was the best conditions in most cases. It decreased the draft force required to break the soil surface crust by about $60 \%$.

Keywords Soil Crust, Organic Materials, Draft Force, Breaking Force.

\section{INTRODUCTION}

Soil surface crust appears in most soils especially in calcareous soils.

The extensive expansion considered to be the most important project influencing on the internal development for the Egyptian society. Most of the new reclaimed areas suffer from many problems such as formation of soil surface crust. This problem occurs in arid and semiarid regions especially in the area between Alexandria and marsa matrouh province (Zein El-Din et al., 2016).

A soil surface crust is a thin, dens and hard layer at the soil surface. It is characterized by greater density and shear strength, but finer pores and lower saturated hydraulic conductivity, than the underlying soil (Fan et al., 2008; Shainberg, 1992).

Agricultural machinery designers face this problem in energy losses for any soil interacting machine. Some soil crust breakers designed to minimize the effect of soil crust (Awadhwal \& Thierstein, 1983). For all these reasons this study investigates the breaking force of the soil surface crust at deferent conditions to stand on the best treatment improving the crust characteristics and minimize the draft force required to break it using a small coulter.

\section{MATERIALS AND METHODS MATERIALS}

A series of experiment were carried out at the soil bin laboratory at Agricultural Engineering Department, of Faculty of Agriculture to investigate the effect of compaction levels and organic matter application levels on the draft force required to break the soil surface crust under surface irrigation. Soil was collected from "El-Hammam Agricultural Experiment Station "Located west of Alexandria. The soil was brought from the Top 30-cm depth layer using a shovel.

\section{Soil testes}

Soil cores were collected from the field for physical, chemical and soil mechanical analysis. 


\section{Soil mechanical analysis}

The soil mechanical analysis was carried out using the hydrometer method. Particle size analysis yielded an average value of $70 \%$ sand, $8 \%$ silt and $22 \%$ clay which classified the soil texture as sandy clay loam soil. Some soil physical properties were determined such as bulk density (B.D.), field capacity (F.C.) standard hydraulic conductivity $\left(\mathrm{k}_{\mathrm{s}}\right)$ and basic infiltration rate (I) (Black et al., 1982; Klute, 1986)

The soil properties are stated in table 1

\begin{tabular}{|c|c|c|c|c|c|c|c|c|c|}
\hline \multirow{2}{*}{$\begin{array}{c}\text { Depth } \\
\text { cm }\end{array}$} & \multicolumn{3}{|c|}{ Particle size } & \multirow{2}{*}{ Texture } & \multirow{2}{*}{$\begin{array}{c}\text { BD } \\
\mathrm{gm} / \mathrm{cm}^{3}\end{array}$} & \multirow{2}{*}{$\begin{array}{c}\text { P.W.P\% } \\
\mathbf{m}^{3} \mathbf{m}^{-3}\end{array}$} & \multirow{2}{*}{$\begin{array}{l}\text { F.C.\% } \\
\mathrm{m}^{3} \mathrm{~m}^{-3}\end{array}$} & \multirow{2}{*}{$\begin{array}{c}\mathrm{ks} \\
\mathbf{m} \mathbf{m ~ h}^{-1}\end{array}$} & \multirow{2}{*}{$\begin{array}{c}\mathbf{I} \\
\mathbf{m} \mathbf{m ~ h}^{-1}\end{array}$} \\
\hline & Sand & Silt & Clay & & & & & & \\
\hline $0-10$ & 70 & 8 & 22 & $\begin{array}{c}\text { Sandy } \\
\text { clay loam }\end{array}$ & 1.39 & 13.78 & 21.55 & 22.57 & 27.682 \\
\hline
\end{tabular}

\section{Soil chemical analysis}

Soluble cations $(\mathrm{Ca}++, \mathrm{Mg}++, \mathrm{N}+$, and $\mathrm{K}+)$ and anions (HCO3-, SO4- - and $\mathrm{Cl}-$ ) were measured in the soil extract according to as well as $\mathrm{pH}$ and electric conductivity (EC). Total calcium carbonate content $(\mathrm{CaCo} 3 \%)$ was determined using the volumetric calcimeter method (Black et al., 1965). Organic matter content (O.M\%) was determined using data of routine analysis for the soil carried out at soil and water science Department, Faculty of Agriculture, Alexandria University and shown in Table 2.

Table (2) some soil chemical properties

\begin{tabular}{|c|c|c|c|c|c|c|c|c|c|c|c|c|}
\hline \multirow{2}{*}{ Depth cm } & \multirow{2}{*}{ pH } & \multirow{2}{*}{$\begin{array}{c}\mathbf{E C} \\
\mathbf{D}_{\mathrm{s}} / \mathbf{m}\end{array}$} & \multicolumn{4}{|c|}{ Cations (meq/I) } & \multicolumn{3}{|c|}{ Anions (meq/I) } & \multirow{2}{*}{$\underset{\%}{\text { OM }}$} & \multirow{2}{*}{$\underset{\%}{\text { O.C }}$} & \multirow{2}{*}{$\begin{array}{c}\mathrm{CaCo} \\
3 \%\end{array}$} \\
\hline & & & $\mathrm{Ca}^{++}$ & $\mathbf{M g}^{++}$ & $\mathrm{Na}^{+}$ & $\mathbf{K}^{+}$ & $\mathrm{HCO}_{3}{ }^{-}$ & $\mathrm{SO}_{4}^{--}$ & $\mathrm{CI}^{-}$ & & & \\
\hline $0-10$ & 7.8 & 5.6 & 17 & 10 & 30.4 & 1.4 & 15 & 8.8 & 30 & 0.77 & 0.45 & 16.45 \\
\hline
\end{tabular}

The soil was air dried and passed through a sieve of $2 \mathrm{~mm}$ to exclude clogs.

\section{Organic materials}

Manure such as Cattle and compost were used as natural conditioner cattle manure considered the best treatment to soil crust (Zein El-Din \& Zin El-Abedin, 1999). The manure matters obtained from the Faculty Farm. Cattle manure was scraped off the concrete floor directly in a semi-solid farm. A composted material was collected from composted pet. Some characteristics of those manure maters was conducted in Soil and Water Science Department, Faculty of Agriculture, Alexandria University and its stated in table 3., the analysis were performed according to the procedure described in the standard methods for Examination of water and wastewater (APHA, 1985).

Table (3) Characteristics of waste materials used in the study

\begin{tabular}{lllll}
\hline Parameter & & Cattle & Compost \\
\hline Bulk density & & $\mathbf{K g} / \mathbf{m}^{\mathbf{3}}$ & 996.7 & 920.8 \\
\hline Total solids & & $\mathbf{K g} / \mathbf{t}$ & 10.25 & 18.7 \\
\hline Volatile solids & & $\mathbf{K g} / \mathbf{t}$ & 8.6 & 10.2 \\
\hline Nutrients contents & & & & \\
\hline Nitrogen & $\mathbf{N})$ & $\mathbf{K g} / \mathbf{t}$ & 5.65 & 4.5 \\
\hline Phosphorus & $\mathbf{( P )}$ & $\mathbf{K g} / \mathbf{t}$ & 1.3 & 1.94 \\
\hline Potassium & $\mathbf{K})$ & $\mathbf{K g} / \mathbf{t}$ & 9.5 & 9.8 \\
\hline Calcium & $\mathbf{C a})$ & $\mathbf{K g} / \mathbf{t}$ & 3.0 & 5.52 \\
\hline Magnesium & $\mathbf{M g})$ & $\mathbf{K g} / \mathbf{t}$ & 1.1 & 0.89 \\
\hline C/N ratio & & & 22 & 15.8 \\
\hline PH & & & 7.0 & 7.0 \\
\hline Dray matter & $\mathbf{( \% )}$ & & 20.85 & 29.9 \\
\hline
\end{tabular}

The application of different manures was based on the inorganic nitrogen available and the commonly used manures at the local farms in Egypt. The levels of manure treatment were introduced in order to ordinary levels used in the local farms 10, 20 and $30 \mathrm{~m}^{3} / \mathrm{fed}$ to achieve approximately $2 \%, 5 \%$ and $8 \%$ organic matter content beside a non-manure (control) treatment. .[12] Manure was mixed good to achieve test homogeneity of the resulting with the soil. The soil treated with manure wetted and left for 14 days. Three cycles of saturation and drying were applied on the soil mixture 
to allow the manure degradation. The soil was collected and sieved remove particle greater than $2 \mathrm{~mm}$. Aggregates large than $2 \mathrm{~mm}$ were broken and add to the soil sample.

\section{Compaction levels}

Three levels of compaction were used (no, medium and heavy compaction) $(0-22-44 \mathrm{KPa})$ chosen to represent the compaction by agricultural equipment the compaction was performed dynamically using hydraulic roller, which adjusted automatically according to the roller weight and the hydraulic power to achieves the desired compaction level.

\section{Methods}

\section{Experiments}

The conducted experiments evaluates the effect of the treatments on the draft force for a coulter knife required for breaking the soil surface crust in the soil bin apparatus.

\section{EXPERIMENTAL APPARATUS}

\section{Soil Bin Apparatus}

The soil surface crust breaking tests were conducted using a fully automated computer controlled soil bin facility for soil dynamics research at the Agriculture Engineering Department, Faculty of Agriculture, Alexandria University.

This facility features the state of the art technology with respect to the instrumentation, controlled and automation (Al-Janobi \& Zain Eldin, 1997).

Apparatus Description

The soil bin used in this study is shown in Figure (1) and it is consisting of the following components:

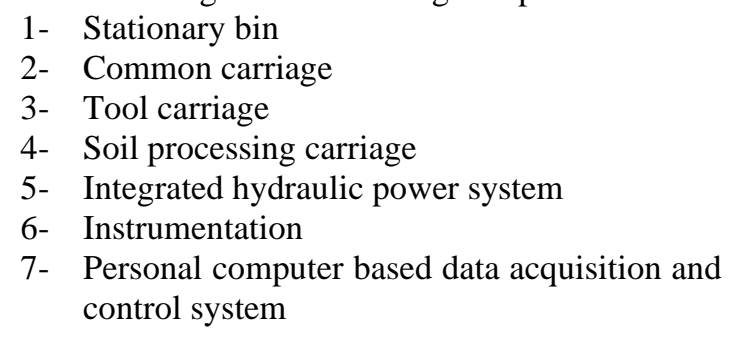

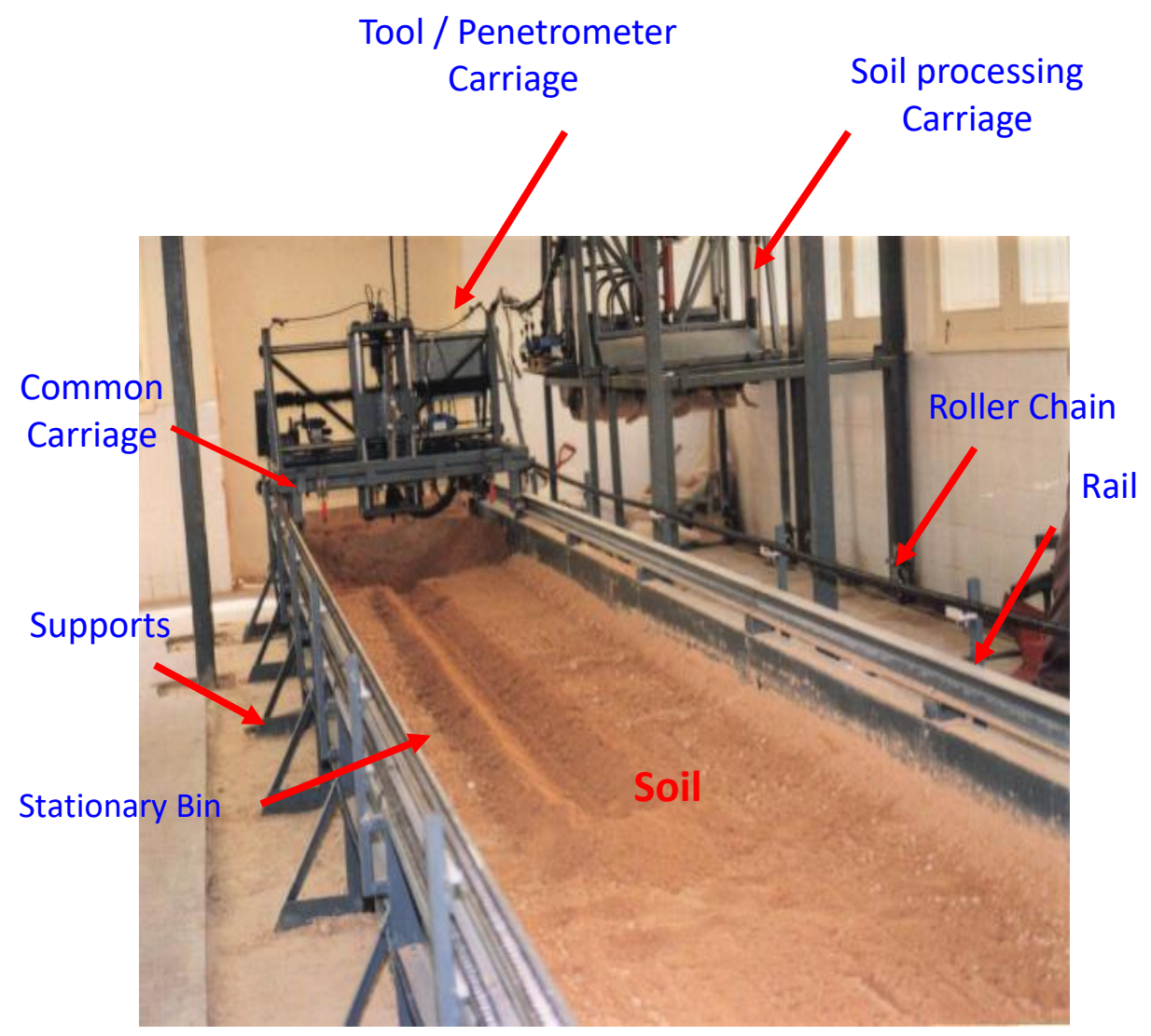

The function and description of the various components of the soil bin facility are:

(1)- The bin is $11 \mathrm{~m}$ long, $1.24 \mathrm{~m}$ wide, and $1 \mathrm{~m}$ depth. It is equipped with two rails on top, one on each side figure (1).

(2)The common carriage is a horizontal frame mounted on wheels which ride on the rails on top of the bin providing support for either the soil processing carriage or the tool/penettometer carriage.
(3)- The soil processing carriage is used to prepare the soil prior to the tests. It consists of a powered rotary tiller, powered roller, leveling blade and a device for adding moisture to the soil. Rotation of the tiller and the roller are accomplished by the use of separate hydraulic motors while their depths of operation are controlled with two hydraulic cylinders.

(4)- The tool/penetrometer carriage positions the tool or penetrometer to the required location across $(\mathrm{X})$ and along $(\mathrm{Z})$ of the bin. Vertical positioning is achieved 
using a vertical ball screw driven by hydraulic motor while lateral positioning is achieved using a horizontal ball screw also driven by a hydraulic motor. This carriage also houses transducers for force and displacement measurement.

When in operation, either the tool or the soil processing carriage is bolted to the common carriage. Which is connected to the drive system through a chain and sprocket arrangements.

(5)- The facility is powered by an integrated hydraulic power system which consists of a $30 \mathrm{hp}(22.5 \mathrm{~kW})$, double shaft electric motor that drives two hydraulic pumps. One of these pumps provides power to a hydraulic motor that drives the carriage along the bin (Z) through a proportional valve and electronic controller. This drive system is designed for a maximum torque of $326 \mathrm{~N} . \mathrm{m}$ at $290 \mathrm{rpm}$.

(6)- The instrumentation and controls of the system control the motion of the carriage, obtains data from the transducers and displays this graphically in real time or at the end of the experiment. The data acquired are also used to control the actuators through the electrohydraulic valves. Data collected are saved on disc for later processing with spreadsheet. The process of preparing the soil, conducting the test and data handling can be operated under manual or fully automatic mode (using personal computer).

\section{INSTRUMENTATION AND CONTROL \\ EQUIPMENT}

Tool Force Transducers

The tool forces are measured with an Extended Octagonal Ring Dynamometer (EORD) which is mounted between the tool mounting plate and the tool bar in such a way that the tool is suspended at the base of the tool bar Figure (2). This dynamometer has been used in different forms for soil dynamics research.
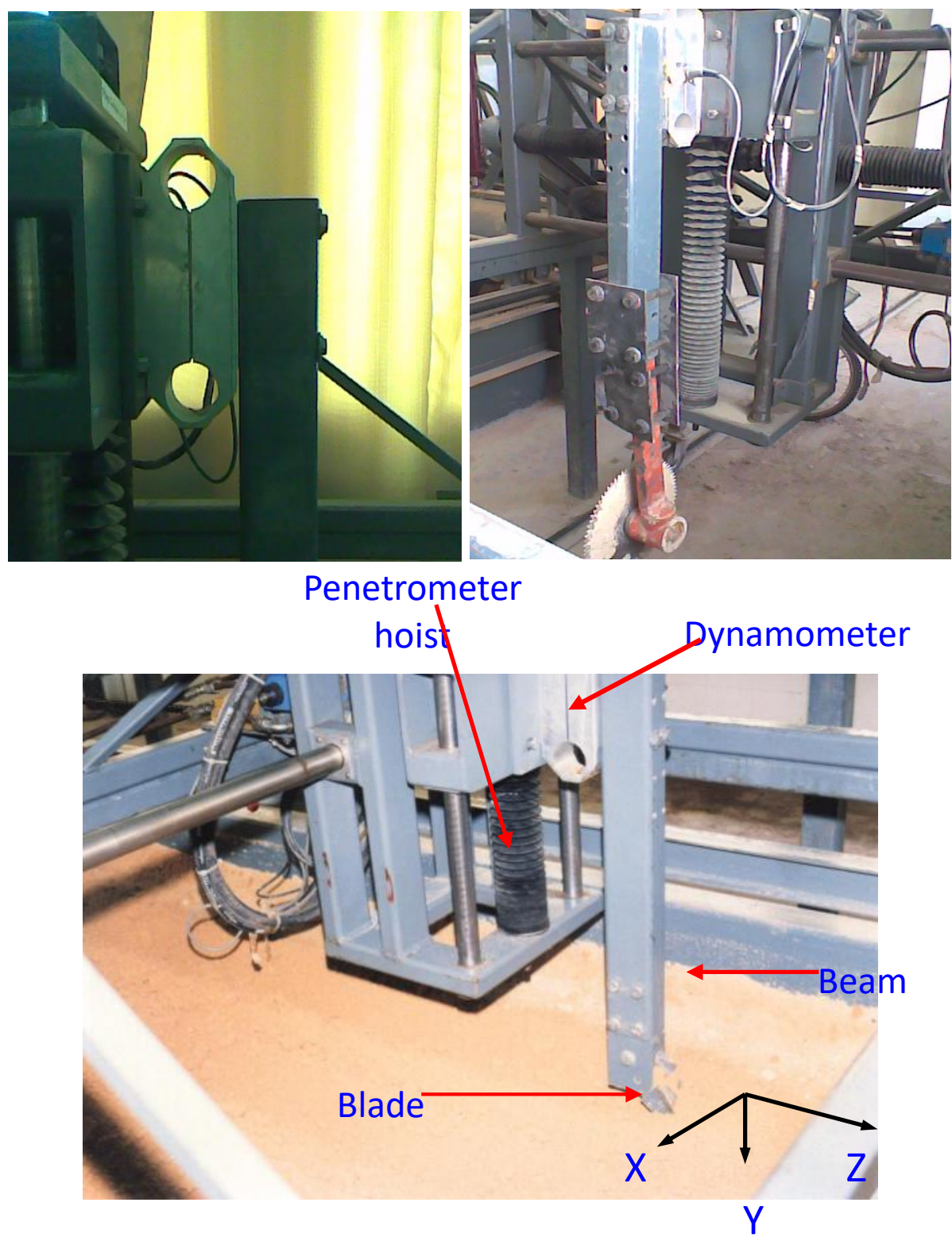
Annual Issue(2021)

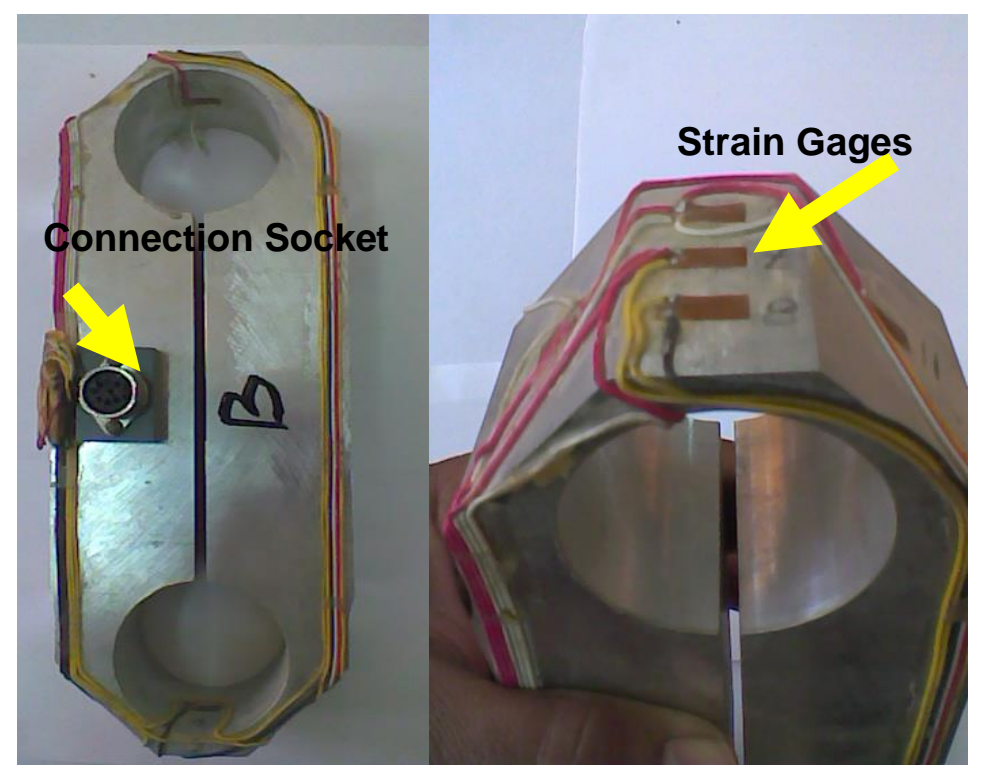

Figure (2) The Shank with extended octagonal ring dynamometer

\section{Coulter Knife}

The coulter knife was used to measure the draft force required to break the soil surface crust (thin and washed underlying layers) under the different treatments.
The coulter knife was conducted from a saw toothed coulter of $25 \mathrm{~cm}$ diameter fixed to a shank using a special made axle having a sleeve bearing with some modifications to facilitate its assembly to the shank. Figure (3).

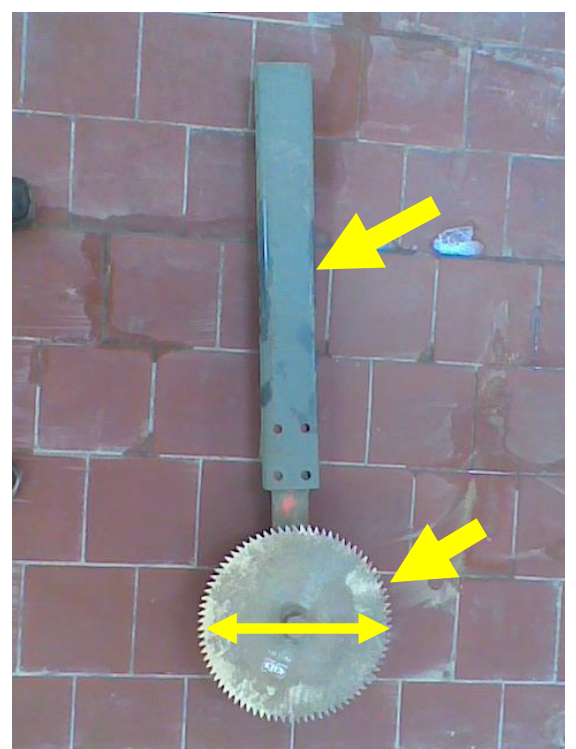

Figure (3): Coulter toothed knife and the shank beam

\section{EXPERIMENTAL METHODS (PROCEDURES)}

\section{Experimental Design}

A split plot experimental design, with three replicates, was used, three levels of compaction (a) nocompaction, (b) medium compaction, $22 \mathrm{KPa}$ (c) heavy compaction $44 \mathrm{KPa}$, were used, three organic material treatments (1) non manure (2) cattle manure (3) composted manure. Three levels of organic matter were used (a) low, $10 \mathrm{~m} 3 /$ fed (b) medium $20 \mathrm{~m} 3 / \mathrm{fed}$ (c) high $30 \mathrm{~m} 3 / \mathrm{fed}$ within each one two types of crust (wet and dry crust) were investigated.

\section{Soil bin experiments}

This set of experiment, were carried out to study the effect of every treatment on the draft force required to break the soil surface crust using a small coulter cutting knife as an important term can help the agricultural machinery designers in design a successful soil surface crust breakers and to take it in consideration when designing any agricultural machine interact with the soil like planters, seed drills, ......etc.[14] 
The $11 \mathrm{~m}$ bin divided to a 3 parts for cattle, non manureand compost ( $3 \mathrm{~m}$ for each) and the rest two meters (one meter in each end of the bin) for preparing carriages.

\section{Soil Preparation}

The soil preparation carriage used in this stage. Organic materials lied on the soil surface and then mixed with the soil using the rotary plow in the same time raising the moisture content using three nozzles to add water this procedure achieves homogeny in distributing the organic matter and the water in soil the mixing operation conducted with the top $30 \mathrm{Cm}$ layer of the soil. After mixing a leveling blade used to level the soil. These two operations repeated several times to achieve homogeny and when the soil is loosening good and mixed with water and organic matter then compacted dynamically using hydraulic roller to the desired compaction level after that the bin is covered with a plastic sheet and left for one day then irrigate the soil (surface irrigation) to saturate the soil.

After degradation, it was a must to use the same carriage to prepare soil to the experiments by tilling with the rotary blow, level (repeated several times to achieve homogeny) and compacting by roller, then irrigated to promote crust.

\section{Knife tillage}

The tool carriage was used in the experiment. The front speed adjusted at $0.85 \mathrm{~m} / \mathrm{sec}(3 \mathrm{Km} / \mathrm{hr})$ as a fixed speed in all experiments.

The tool carriage can measure the forces using the octagonal ring dynamometer which connected directly to the tillage shank. This dynamometer can read the forces in the three directions $\mathrm{X}, \mathrm{Y}, \mathrm{Z}$ through a group of electronic strain gages distributed on its surface in a specific positions to measure the deflection (strain) in the dynamometer metal and transfer it to the data acquisition system in mille volts $(\mathrm{mV})$ which delivers it to the computer then convert the measurements (100 reading/sec) from its row case $(\mathrm{mV})$ to $\mathrm{Kg}$ and n(newton) automatically.[15]

\section{RESULTS AND DISCUSSION}

The results of the experiments were collected and plotted to investigate the effect of the different treatments at the soil surface crust breaking force.

Breaking soil surface crust (Soil bin experiments)

The test was carried out at the wet crust (1 day after irrigation) and dry crust (14 day after irrigation) at 3 levels of tool depth 1,3 , and $5 \mathrm{~cm}$ to investigate the breaking force at the thin layer and the washed underlying layer.

The measured data from the soil bin apparatus stated in Table (4). 
Annual Issue(2021)

Table (4): Draft force measured for every treatment (n).

\begin{tabular}{|c|c|c|c|c|c|c|c|c|c|}
\hline \multirow{4}{*}{$\begin{array}{c}\text { Compaction } \\
\text { Level } \\
\text { (KPa) }\end{array}$} & \multirow{4}{*}{ Type of crust } & \multirow{4}{*}{ 营氙 } & \multicolumn{7}{|c|}{ Treatment } \\
\hline & & & \multirow{2}{*}{ non Manure } & \multicolumn{3}{|c|}{ Cattle } & \multicolumn{3}{|c|}{ compost } \\
\hline & & & & $10 \mathrm{~m}^{3} / \mathbf{f d}$ & $20 \mathrm{~m}^{3} / \mathbf{f d}$ & $30 \mathrm{~m}^{3} / \mathbf{f d}$ & $10 \mathrm{~m}^{3} / \mathbf{f d}$ & $20 \mathrm{~m}^{3} / \mathbf{f d}$ & $30 \mathrm{~m}^{3} / \mathrm{fd}$ \\
\hline & & & \multicolumn{7}{|c|}{$\begin{array}{l}\text { Draft Force (n) } \\
\end{array}$} \\
\hline \multirow{6}{*}{ 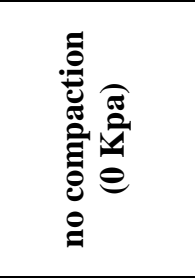 } & \multirow{3}{*}{ Wet Crust } & 1 & 48.17 & 39.53 & 17.46 & 9.01 & 43.36 & 29.33 & 14.12 \\
\hline & & 3 & 69.16 & 56.11 & 37.67 & 27.91 & 58.66 & 44.73 & 31.35 \\
\hline & & 5 & 89.37 & 72.01 & 51.11 & 44.05 & 76.62 & 62.49 & 51.91 \\
\hline & \multirow{3}{*}{ Dray Crust } & 1 & 60.82 & 49.64 & 20.21 & 14.78 & 57.98 & 48.46 & 30.99 \\
\hline & & 3 & 81.91 & 70.44 & 38.16 & 27.55 & 78.77 & 59.25 & 45.84 \\
\hline & & 5 & 119.09 & 94.86 & 56.51 & 40.99 & 102.32 & 69.95 & 60.00 \\
\hline \multirow{6}{*}{ 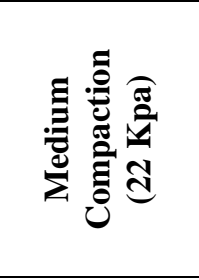 } & \multirow{3}{*}{ Wet Crust } & 1 & 58.86 & 56.41 & 25.21 & 16.11 & 57.09 & 39.44 & 25.11 \\
\hline & & 3 & 80.83 & 69.75 & 54.64 & 40.87 & 76.81 & 59.74 & 47.25 \\
\hline & & 5 & 99.57 & 95.26 & 76.62 & 61.00 & 98.00 & 82.31 & 77.09 \\
\hline & \multirow{3}{*}{ Dray Crust } & 1 & 73.58 & 66.81 & 47.38 & 35.17 & 68.77 & 56.02 & 42.00 \\
\hline & & 3 & 101.53 & 90.55 & 69.85 & 52.23 & 96.63 & 77.79 & 63.17 \\
\hline & & 5 & 138.32 & 113.60 & 96.43 & 85.53 & 124.78 & 110.36 & 91.76 \\
\hline \multirow{6}{*}{ 施 } & \multirow{3}{*}{ Wet Crust } & 1 & 64.16 & 61.12 & 30.21 & 21.99 & 62.88 & 43.66 & 37.78 \\
\hline & & 3 & 93.20 & 79.66 & 62.00 & 57.61 & 86.13 & 73.67 & 69.08 \\
\hline & & 5 & 118.80 & 102.32 & 79.26 & 62.21 & 111.05 & 87.21 & 73.76 \\
\hline & \multirow{3}{*}{ Dray Crust } & 1 & 69.45 & 67.59 & 50.82 & 45.16 & 68.67 & 57.98 & 44.43 \\
\hline & & 3 & 127.53 & 98.20 & 85.94 & 77.01 & 112.91 & 89.96 & 80.86 \\
\hline & & 5 & 198.16 & 162.75 & 120.37 & 104.60 & 182.27 & 128.81 & 118.58 \\
\hline
\end{tabular}

The results shows that type of crust, compaction level, type of organic material and the application rate of manure matter have a significant effect of the draft force.

\section{Effect of Compaction level}

Three compaction levels were used in this set of experiments "No compaction ( $0 \mathrm{KPa}$ ), Medium compaction $(22 \mathrm{KPa})$ and Heavy compaction $(44 \mathrm{KPa})$ " to investigate its effect on the draft force required to break the soil surface crust.

To evaluatethe effect of compaction level on the draft force, we must neglect the effect of the other factors such as organic matter and its application rate. So, the comparison will be with thenon manure treatments. Generallythe results shows that increasing compaction level increased the draft force.

The increasing ratio in draft force was calculated using the following equation

$$
I R=\frac{d_{i}-d_{o}}{d_{o}} \times 100
$$

Where:

$$
\begin{array}{lll}
\text { IR } & : & \text { Increasing ratio } \\
\text { do } & : & \text { Draft at no compaction } \\
\text { di } & : & \text { Draft at the compaction level }
\end{array}
$$

The increasing ratio is stated in Figures(4-5). 


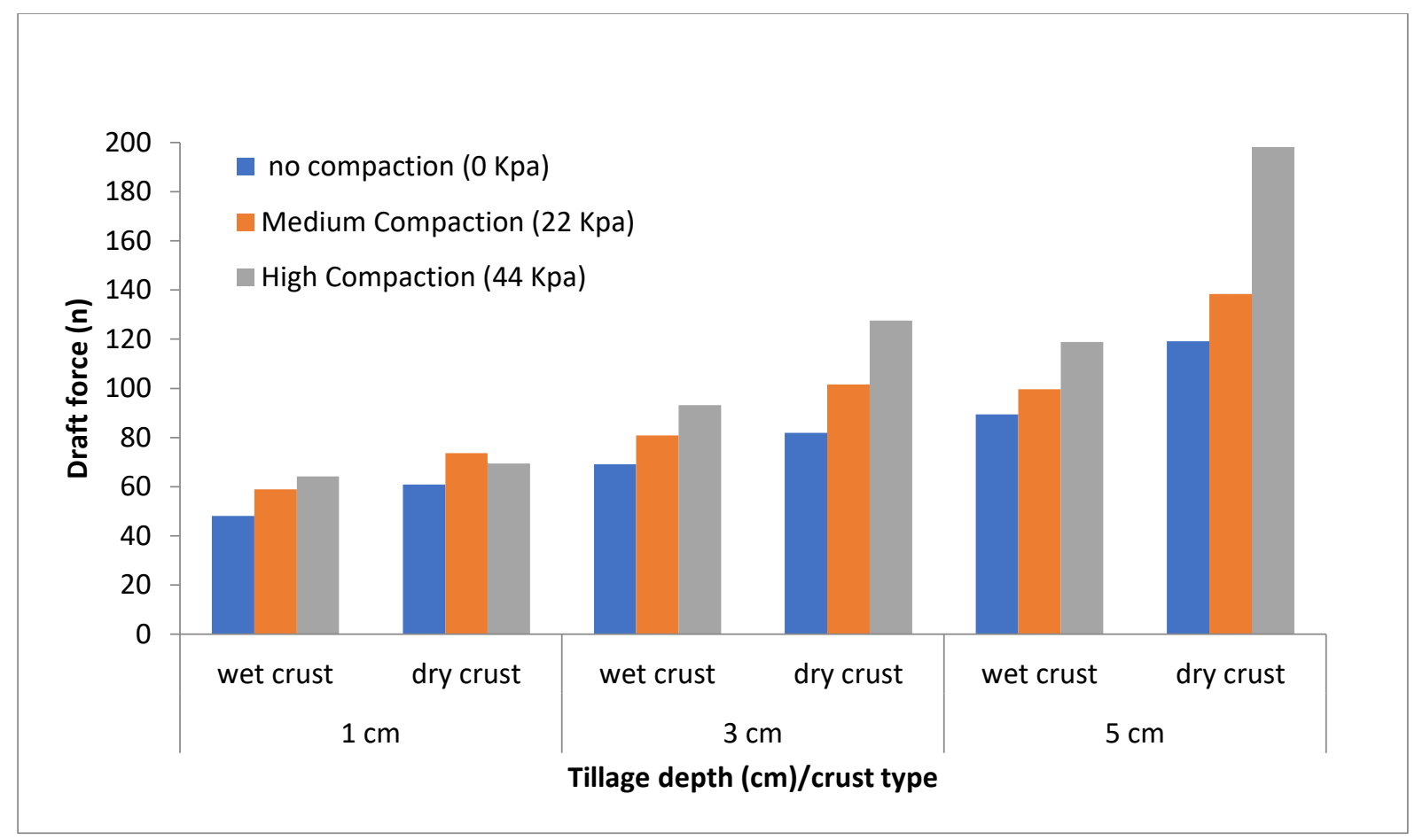

Figure (4): Effect of compaction Level on draft force

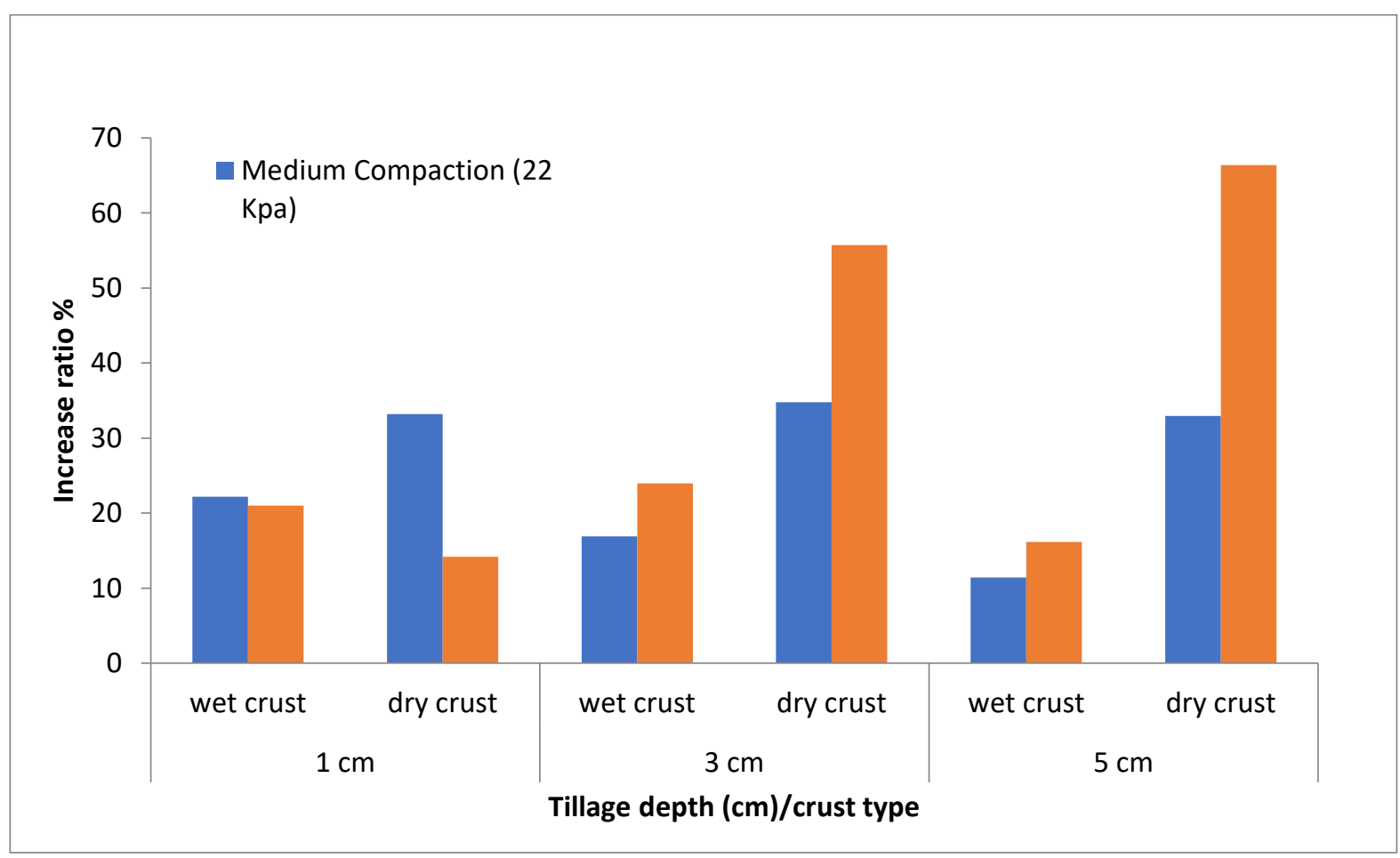

Figure (5): Effect of compaction Level on draft force

The results show the effect of compaction level on the draft force required to break the soil surface crust:Increasing the compaction level from no compaction $(0 \mathrm{KPa})$ to medium $(22 \mathrm{KPa})$ increased the draft force by $(22.2,16.9$ and $11.4 \%)$ for 1,3 and $5 \mathrm{~cm}$ tillage depth respectively at the wet crust type and by type and by (14.2, 55.7 and $66 \%$ ) for 1,3 and $5 \mathrm{~cm}$ tillage depth respectively at the dry crust type.
(21, 24 and $16.1 \%$ ) for 1,3 and $5 \mathrm{~cm}$ tillage depth respectively at the dry crust type.

Increasing the compaction level from medium compaction $(22 \mathrm{KPa})$ to heavy $(44 \mathrm{KPa})$ increased the draft force by $(33.2,34.8$ and $32.9 \%)$ for 1,3 and $5 \mathrm{~cm}$ tillage depth respectively at the wet crust

So generally at the thin surface layer ( $1 \mathrm{~cm}$ tillage depth) there is no significant deference between the two 
compaction level in wet crust but in dry crust the gap between the two steps of compaction is greater and it shows that the first step of increasing compaction had a higher effect than the second step. At the other tillage depths the trend had reversed, the increase of compaction increase the draft force and the effect at the dry crust is greater than the effect in wet crust and the ratio increased significantly with the increase in tillage depth.

\section{Effect of manure matter type}

Two waste materials were used in this set of experiments to investigate the draft force required to break the soil surface crust as affected by manure matter.

To evaluate the effect of manure matter we must neglect the other factors such as manure matter application rate and compaction level. So, the comparison was with the compaction $(0 \mathrm{KPa})$ and at the low level of manure matter $\left(10 \mathrm{~m}^{3} / \mathrm{fed}\right)$ treatments.

Generally the results show that adding manure matter decreased the draft force significantly.

The decreasing ratio in draft as affected by treating the soil with the waste materials was calculated using the following equation.

$$
D R=\frac{d_{n}-d_{m}}{d_{n}} \times 100
$$

Where:

$$
\begin{array}{lll}
\text { DR } & : & \text { Decreasing ratio } \\
\mathrm{dn} & : & \text { Draft at non manure treatment } \\
\mathrm{dm} & : & \text { Draft at the measured treatment }
\end{array}
$$

\begin{tabular}{|c|c|c|c|c|c|c|c|c|}
\hline \multirow{3}{*}{ 3ิ } & \multirow{3}{*}{ 莺 } & \multirow{3}{*}{ 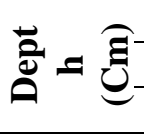 } & \multicolumn{6}{|c|}{ Manure Treatment } \\
\hline & & & \multicolumn{3}{|c|}{ Cattle } & \multicolumn{3}{|c|}{ compost } \\
\hline & & & $10 \mathrm{~m}^{3} / \mathrm{fed}$ & $20 \mathrm{~m}^{3} / \mathrm{fed}$ & $30 \mathrm{~m}^{3} / \mathrm{fed}$ & $10 \mathrm{~m}^{3} / \mathrm{fed}$ & $20 \mathrm{~m}^{3} / \mathrm{fed}$ & $30 \mathrm{~m}^{3} / \mathrm{fed}$ \\
\hline \multirow{6}{*}{ ؛ } & \multirow{3}{*}{$\sum^{ \pm}$} & 1 & 17.92 & 63.75 & 81.29 & 9.98 & 39.10 & 70.69 \\
\hline & & 3 & 18.87 & 45.53 & 59.64 & 15.18 & 35.32 & 54.67 \\
\hline & & 5 & 19.43 & 42.81 & 50.71 & 14.27 & 30.08 & 41.92 \\
\hline & \multirow{3}{*}{$\stackrel{\overrightarrow{0}}{0}$} & 1 & 18.39 & 66.77 & 75.70 & 4.68 & 20.32 & 49.05 \\
\hline & & 3 & 14.01 & 53.41 & 66.37 & 3.83 & 27.66 & 44.04 \\
\hline & & 5 & 20.35 & 52.55 & 65.58 & 14.09 & 41.27 & 49.62 \\
\hline \multirow{6}{*}{ 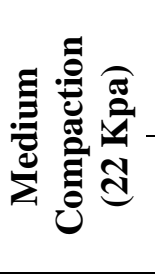 } & \multirow{3}{*}{$\sum^{\overline{0}}$} & 1 & 4.17 & 57.17 & 72.63 & 3.00 & 33.00 & 57.34 \\
\hline & & 3 & 13.71 & 32.40 & 49.44 & 4.98 & 26.09 & 41.55 \\
\hline & & 5 & 4.33 & 23.05 & 38.74 & 1.58 & 17.34 & 22.58 \\
\hline & \multirow{3}{*}{$\overrightarrow{0}$} & 1 & 9.20 & 35.60 & 52.20 & 6.53 & 23.87 & 42.92 \\
\hline & & 3 & 10.82 & 31.21 & 48.56 & 4.83 & 23.38 & 37.78 \\
\hline & & 5 & 17.87 & 30.28 & 38.17 & 9.79 & 20.21 & 33.66 \\
\hline \multirow{6}{*}{ 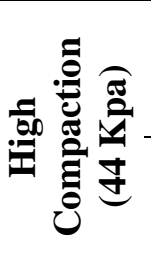 } & \multirow{3}{*}{$\sum^{ \pm}$} & 1 & 4.74 & 52.91 & 65.72 & 1.99 & 31.95 & 41.11 \\
\hline & & 3 & 14.53 & 33.47 & 38.18 & 7.58 & 20.95 & 25.88 \\
\hline & & 5 & 13.87 & 33.28 & 47.63 & 6.52 & 26.59 & 37.91 \\
\hline & \multirow{3}{*}{ ڤُ } & 1 & 2.68 & 26.84 & 34.98 & 1.13 & 16.53 & 36.03 \\
\hline & & 3 & 23.00 & 32.62 & 39.62 & 11.46 & 29.46 & 36.60 \\
\hline & & 5 & 17.87 & 39.26 & 47.22 & 8.02 & 35.00 & 40.16 \\
\hline
\end{tabular}

The decrease ratio as affected by adding the manure materials is stated in Table (5).

The draft force required to break the soil surface crust as affected by adding manure matter at both crust types wet and dry crust and at the thin layer (1 cm tillage depth) is plotted in figure (6). 


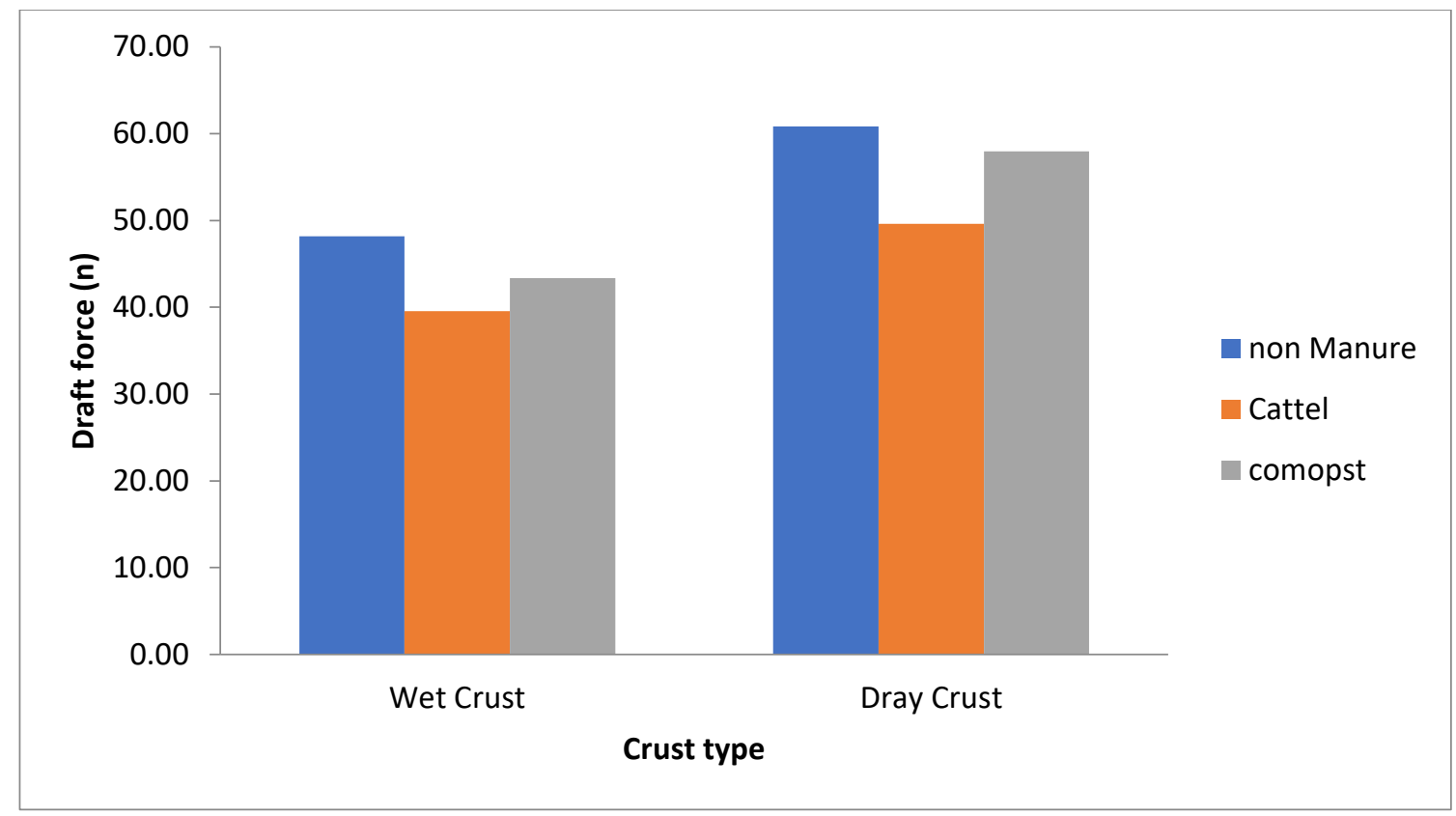

Figure (6): effect of manure matter

Adding waste materials decreased the draft force required to break the soil surface crust significantly by $17.9 \%$ and $10 \%$ (at $1 \mathrm{Cm}$ tillage depth) for cattle and compost manure respectively at the wet crust type, and the reduction ratio was $18.4 \%$ and $4.7 \%$ (at $1 \mathrm{Cm}$ tillage depth) for cattle and compost manure respectively at the dry crust type. It shows that cattle manure had a greater effect of the draft force than compost manure.

The effect of the waste materials at the underlying washed layer was greater than the thin layer: The reduction ratio achievedby adding cattle manure was $18.9 \%$ and $19.4 \%$ at 3 and $5 \mathrm{~cm}$ tillage depth respectively for wet crust type and it was $14 \%$ and $20.4 \%$ at 3 and $5 \mathrm{~cm}$ tillage depth respectively for dry crust type. The reduction ratio achieved by adding compost manure was $15.2 \%$ and $14.2 \%$ at 3 and $5 \mathrm{~cm}$ tillage depth respectively for wet crust type and it was $3.8 \%$ and $14.1 \%$ at 3 and $5 \mathrm{~cm}$ tillage depth respectively for dry crust type.

It's noticed that the reduction at $3 \mathrm{~cm}$ tillage depth were the smallest than the reduction at 1 and $5 \mathrm{~cm}$ tillage depth.

\section{Effect of manure matter application rate}

Three application rates were used in this set of experiments: low $\left(10 \mathrm{~m}^{3} / \mathrm{fed}\right)$, medium $\left(20 \mathrm{~m}^{3} / \mathrm{fed}\right)$ and high $\left(30 \mathrm{~m}^{3} / \mathrm{fed}\right)$ to investigate its effect on the draft force required to break the soil surface crust.

To evaluate the effect of manure matter application rate we must neglect the other factors such as compaction level. The draft force measured for every treatment and the reduction ratio achieved by the different manure matter application rates are stated in table (5)and plotted in figure (9). 


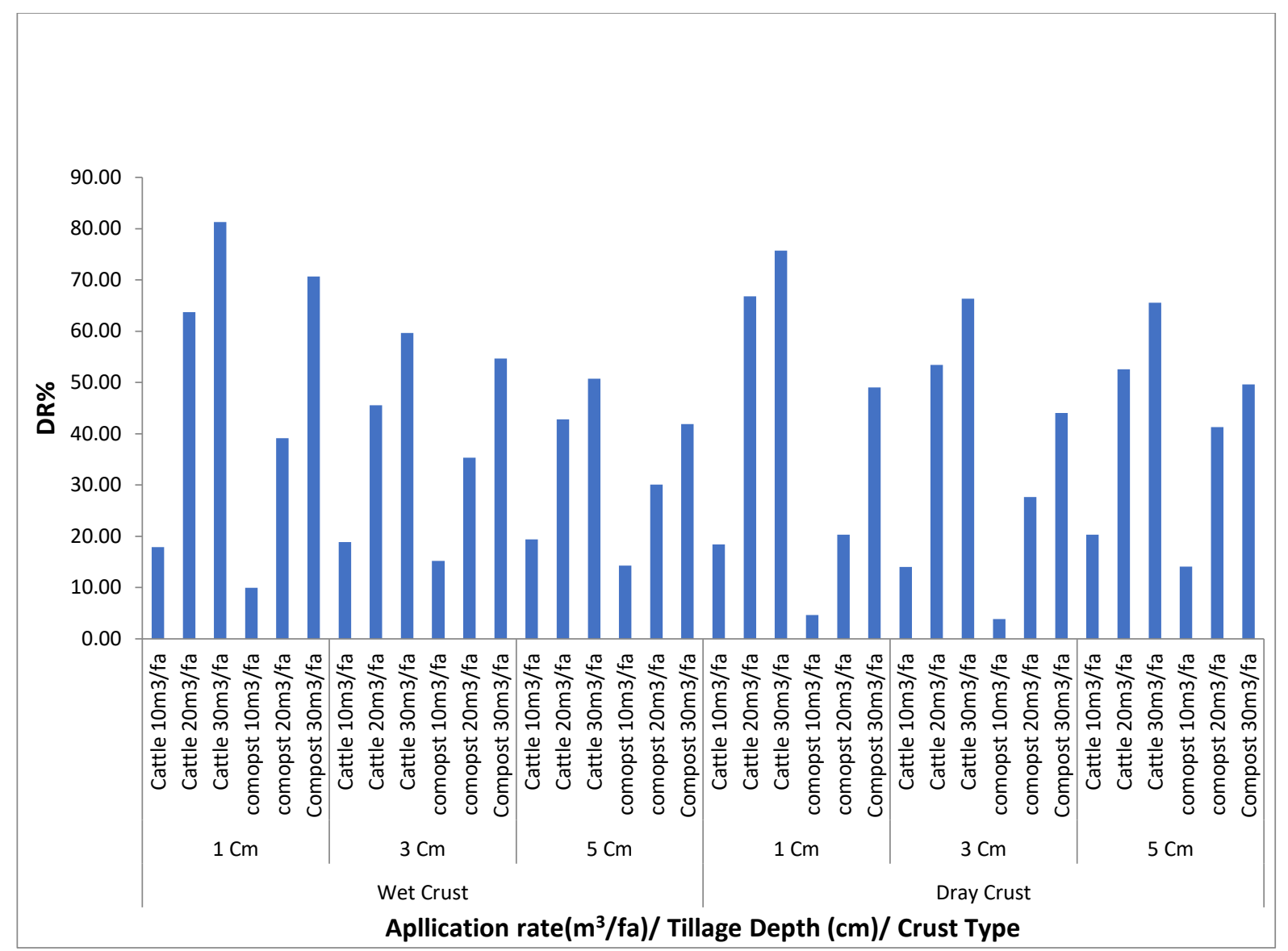

Figure (9): Reduction ratio as affected by manure matter application rates

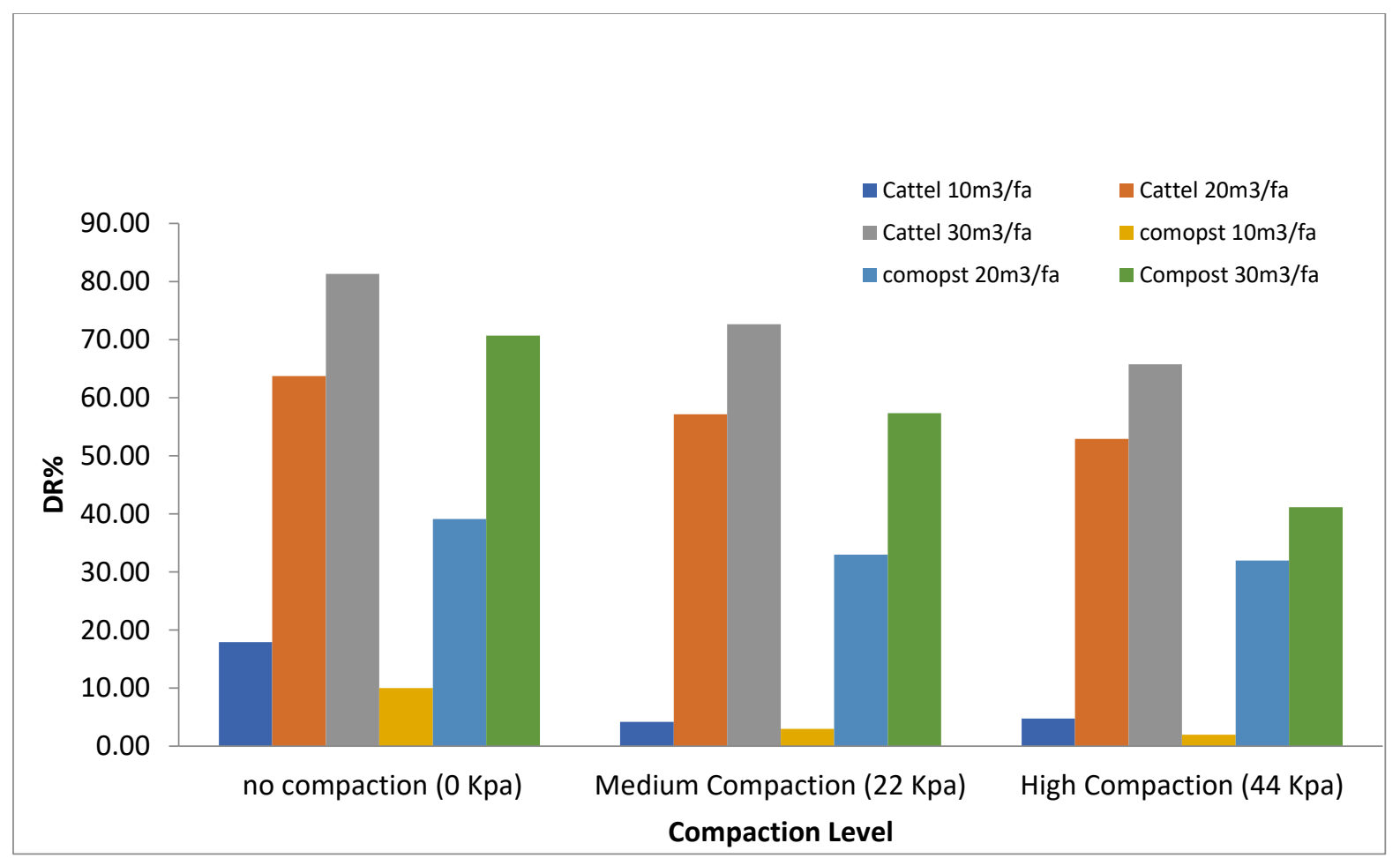

Figure (15): effect of organic matter on the draft force at $1 \mathrm{Cm}$ depth,wet crust and all compaction levels 
Increasing compaction level increased the draft force required to break the soil surface crust in all manure treatment and its application rates.Adding manure matter not only didn't reduce the harmful effect of compaction but it magnified its effect.

Compost manure had a better improvement of the harmful effect of the compaction than cattle manure in all application rates. In other hand the total improvement of soil surface crust (minimum draft force) achieved using cattle manure in all application rates.

\section{CONCLUSION}

In general addition of organic matter improves the soil characteristics whilecompaction levels decrease this improvement. It may be concluded that:

- Cattle manure is considered the best waste material to treat soil surface crust especially at the Medium application rate $\left(20 \mathrm{~m}^{3} / \mathrm{fed}\right)$, it decreases the vice effect of compaction levels andit has the major effect of the draft force and the crust strength.

- The best cattle manure application rate is the medium rate $(20 \mathrm{~m} 3 / \mathrm{fed})$ it gives the higher decrease of the draft force required to break the soil surface crust by more than $60 \%$.

\section{REFERENCES}

[1] Al-Janobi, A. A., \& Zain Eldin, A. M. (1997). Development of a Soil-Bin Test Facility for Soil. Tillage Tool Interaction Studies, Research Bulletin, 72, 5-26. reserchgate.net.

[2] Zein Eldin, Abdalla \& Zin El-Abedin, Tarek \& Rasha.M.Youssef \& Abou Kheir, Mostafa. (2018). Estimating an Engineering Index for Soil Surface Crust Formation.

[3] APHA. (1985). Standard method for the examination of water and waste water, 13th.ed. New York N.Y. American Public Health Association.

[4] Awadhwal, N. K., \& Thierstein, G. E. (1983). Development of rolling-type soil crust breaker. Agricultural Mechanization in Asia, Africa and Latin America, 14(4), 31-34.

[5] Black, C. A., Evans, D. D., Ensinger, L. E., \& Clark. (1982). Methods of Soil Analysis.
American Society of Agronomy Publishers,Madison.

[6] Black, C. A., Evans, F., Ensminger, J., White, F., Clar, J., \& Dinaver, R. (1965). Method of soil analysis II. Chemical and Microbiological Properties, 9.

[7] Fan, Y., Lei, T., Shainberg, I., \& Cai, Q. (2008). Wetting rate and rain depth effects on crust strength and micromorphology. Soil Science Society of America Journal, 72(6), 1604-1610.

[8] Klute, A. A. (1986). Methods of Soil Analysis". American Society of Agronomy, Inc. Publishers, Madison, Wisconsin, USA.

[9] Shainberg, I. (1992). Chemical and mineralogical components of crusting. Soil Crusting: Chemical and Physical Processes, in: Sumner M.E., Stewart B.A. (Eds.), Soil Crusting: Chemical and Physical Processes, Lewis, Boca Raton, FL, pp. 33-53.

[10] Zein El-Din, A. M., Hassan, H. H., Abou ElKheir, M. M., \& Youssef, R. M. (2016). Controlling soil surface crust formation using nanosized sulfonated polyaniline. J Soil Water Conserv, 1(1), 1-9.

[11] Zein El-Din, A. M., \& Zin El-Abedin, T. K. (1999). Soil surface crust as affected by different organic materials and compaction levelse.". Misr Journal of Agricultural Engineering, 16(4), 675-700.

[12] Zein Eldin, Abdalla \& Zin, Thae \& Youssef, Refat \& Abou Kheir, Moulham. (2018). Estimating an Engineering Index for Soil Surface Crust Formation.

[13] Zein Eldin, Abdalla \& Mohamed.A.E, \& Magda.H.H, \& Gamal.A.S,. (2018). Reducing Energy Required For Breaking Soil Crust By Using Organic Materials. reserchgate.net.

[14] Zein Eldin, Abdalla \& Aljanobi, Abdulrahman. (2021). Development of soil-bin test facility for soil tillage tool interaction studies. reserchgate.net.

[15] Zain El-Din, Abdalla, Rasha. M. Youssef, Reda.G.Abdel Hamied. (2021). Mathematical models for predicating draft forces of tillage tools: A Review. Journal of the Advances in Agricultural Researches, 26(2), 48-52. 


\section{الملخص العربي:}

\section{تخفيض الطاقة اللازمة لتكسير القشرة الصلبة للتربة باستخدام مواد عضوية}

\section{محمد أحمد إبراهيم، عبد الله مسعد زين الدين²، ماجدة أبو المجد3، جمال عطية شرف4}

$$
1 \text { خبير الملكية الفكرية بشركة سماس للملكية الفكرية - مصر }
$$

2 أستاذ الهندسة الزراعية والنظم الحيوية و عميد كلية الزراعة - الثاطبي - جامعة الإسكندرية

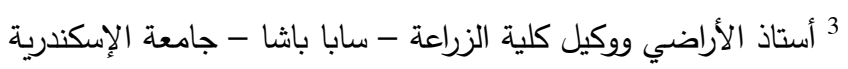

4 أستاذ الهندسة الزراعية بقسم الأراضي والكيمياء الزراعية كلية الزراعة - سابا باشا - جامعة الإسكندرية

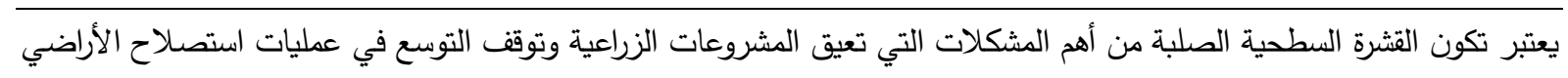
الجديدة لما لها من تأثير على خصائص التربة وإعاقة نمو البادرات واستهلاك قدراً أعلى من الطاقة في اعمليات الزراعية المختلفة.

تم إجراء مجموعة من التجارب لبحث تأثير مستويات مختلفة من الكبس وأنواع مختلفة من الأمواد العضوية بمعدلات إضافة مختلفة

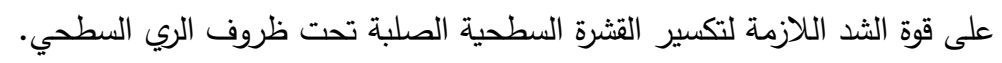

تمت التجارب على تربة رملية لومية تحتوي على نسبة 16.45\% من كربونات كالسيوم مأخوذة من مدينة الحمام بمحافظة مطروح

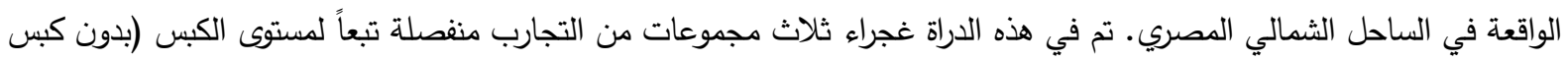

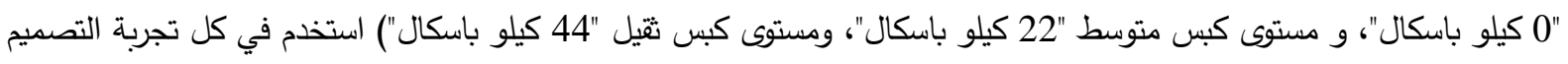

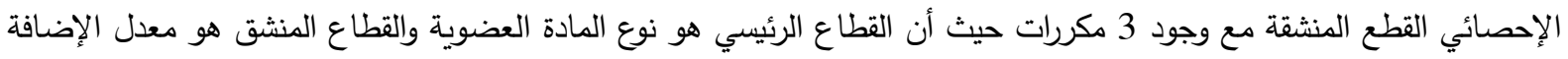

$$
\text { (ثلاث معدلات 10، } 20 \text { ،و30 م3/فدان). }
$$

تم دراسة قوى الثد باستخدام سكين صغير لتكسير القشرة السطحية الصلبة للتربة وأجريت الياسات باستخدام جهاز قياس الثد المعلي والمدار بالحاسب الآلي.

تتلخص نتائج الدراسة في أن لزيادة مستويات الكبس تأثير عكسي على خصائص القشرة السطحية الصلبة. زيادة مستوى الكبس يزيد

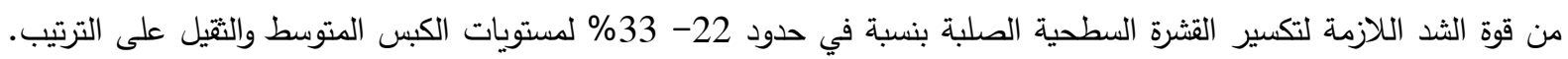

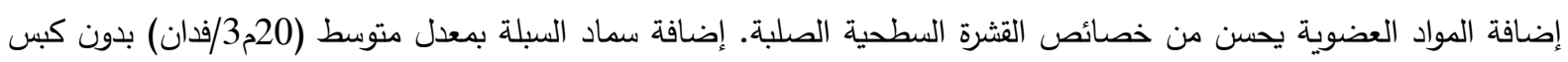
للتربة أعطى أفضل نتائج في معظم الحالات. حيث خفض من قوة الثد اللازمة لتكسير القشرة السطحية الصلبة بنسبة حوالي 60\% 